\title{
JURNAL MANAJEMEN BISNIS DAN KEWIRAUSAHAAN
}

Volume 3/No.3/Mei /2019

e-ISSN 2598-0289

Terbit enam kali dalam setahun. Berisi tulisan yang diangkat dari hasil penelitian di bidang Ilmu Manajemen dan Kewirausahaan.

\section{Ketua Dewan Penyunting}

Prof. Ir. Carunia Mulya Firdausy, MA, Ph.D - Universitas Tarumanagara

\section{Wakil Ketua Dewan Penyunting}

Dr. Eko Harry Susanto - Universitas Tarumanagara

\author{
Anggota Dewan Penyunting \\ Dr. Ir. Agus Zainul Arifin, MM - Universitas Tarumanagara \\ Dr. Eddy Supriyatna MZ, M.HUM - Universitas Tarumanagara \\ Dr. Anas Lutfi, MM, MKN - Universitas Indonesia \\ Dr. Hardius Usman, M.Si - Universitas Indonesia \\ Dr. Indra Widjaja, SE, MM - Universitas Tarumanagara \\ Dr. Hetty Karunia Tunjung Sari - Universitas Tarumanagara
}

\author{
Sekretariat \\ Maria Benedicta, SE \\ Stephanie Pane, SE, MM
}

Alamat Penyunting dan Tata Usaha: Program Studi MM Untar, Kampus 1, Gedung Utama, Lantai 14, Jl. Let. Jen. S. Parman No. 1 Grogol, Jakarta 11440. Telp. (62-21) 5655806 dan Fax. (62-21) 5655808. Email: mmuntar@tarumanagara.ac.id 
JURNAL MANAJEMEN BISNIS \& KEWIRAUSAHAAN

Mei 2019, Volume 3, No 3

e-ISSN 2598-0289

Halaman 1-112

Pengaruh Kredibilitas, Reputasi, Dan Kemampuan Persuasif Food Bloggers

Terhadap Intensi Konsumen Dalam Memilih Sebuah Restoran

Melly Audina

01-07

Analisis Pengaruh Car, Npl, Nim, Bopo Dan Ldr Terhadap Roe Pada

Bank Umum Swasta Nasional Devisa Di Indonesia

Monica

08-17

Pengaruh Kualitas Pelayanan, Reputasi Perusahaan, Dan Kepuasaan Nasabah

Dalam Menciptakan Loyalitas Nasabah Pada Penggunaan Mobile Banking Di Pt Bank Xyz

Octario Edo Setyawan Dan Anas Lutfi

$18-23$

Faktor Determinan Inormasi Pengguna Mobile Banking Bank Xyz

Adi Purnama Dan Carunia M. Firdausy

24-31

Pengukuran Kinerja Perusahaan Pada Pt. Yyy Dengan Menggunakan

Metode Balanced Scorecard

Richardson Harjanto Nurdin

Pengaruh Service Quality, Brand Image Terhadap Brand Loyalty Dengan

Brand Trust Sebagai Mediasi

Sammy Natanael

Pengaruh Inflasi, Suku Bunga As, Harga Emas, Harga Minyak Bumi, Inflasi As

Dan Kurs Rupiah Terhadap Indeks Sektoral Di Indonesia

Sylvin Antonius

Analisis Pengaruh Faktor -Faktor Total Quality Management (Tqm)

Terhadap Kinerja Perusahaan Pt Xyz

Vania Novianty

Analisis Strategi Bisnis Pada Pt. Galleon Cahaya Investama Untuk

Meningkatkan Daya Saing Dalam Persaingan Di Pasar

Yakobus Luke

Analisis Pengawasan Serta Pengaruh Kawasan Berikat Terhadap Arus Kas, Beban Pajak

Dan Aktivitas Ekspor Pt.Xyz

Deby Valentina

Pengaruh Brand Loyalty, Word OfMouth, Dan Celebrity Endorsement

Terhadap Repurchase Intention

Leonardo Charles Ferdinands

Pengaruh Orientasi Pasar Terhadap Kinerja Perusahaan Dengan Komitmen Organisasi

Dan Kemampuan Pemasaran Sebagai Variabel Mediasi

(Studi Empiris Pada Perusahaan Sektor Ritel Di Dki Jakarta)

Ongky Alex Sander

80-

89

Pengajuan Artikel Jurnal Analisis Pengembangan Bisnis Kafe District Resto \& Bar

Untuk Meningkatkan Daya Saing

Tommy Halim Wijaya Dan Eko Harry Susanto

90-

95

Pengaruh Profitabilitas, Board Gender, Dan Likuiditas Terhadap Nilai Perusahaan Dengan Kebijakan Dividen Sebagai Variabel Moderasi

(Studi Empiris Pada Perusahaan Manufaktur Yang Bergerak Dibidang 
Consumer Goods Yang Terdaftar Di Bei Periode 2011-2016)

Elisabeth Octavia Kamal Dan Indra Widjaja

96-103

Faktor-Faktor Yang Mempengaruhi Return Saham Perusahaan Pertambangan Batubara

Di Bei Periode 2008-2015

Rafail Widarko Dan Carunia Mulya Firdausy

104-

112 